\title{
MRS Committees Focus on Planning, Outreach to Materials Community
}

Chairs of the standing committees of the Materials Research Society have defined their goals for 1991, emphasizing the common themes of planning and outreach to the materials community. The theme of planning involves not only fiscal awareness but efforts to chart an effective longterm course that will act, says John Baglin, chair of the Long-Range Planning Committee, "not as a constraint, but as a catalyst to future achievement."

The theme of outreach spans many areas both national and international as well as new dimensions of information and service-endeavors with other societies, involvement with materials science issues, information flow to and from federal agencies, new levels of activity with industry, academia and government. As Membership Committee chair Michael Kelley says, "We are continuously expanding our endeavors to invite and retain in MRS membership all those who can benefit from it, an ever-widening circle as our vision of
MRS grows."

In the coming year, MRS members can also expect efforts to maintain and refine the vitality of MRS meetings, foster MRS Sections, ensure timely and relevant publications, and recognize excellence and achievement in materials science.

For more information about the specific activities of the MRS standing committees, contact the committee chairs identified below.

\section{Academic Affairs Committee}

Chair, Aubrey L. Helms Jr., Lam Research, 49026 Milmont Drive, Fremont, CA 94538; phone (415) 490-7782; fax (415) 659-8325.

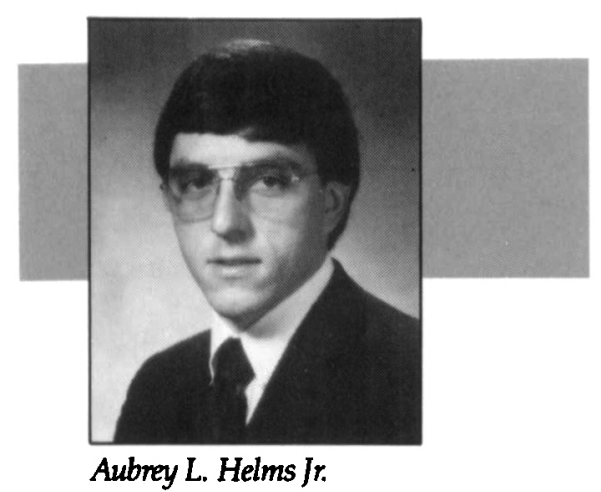

The MRS Academic Affairs Committee coordinates the support and activities of the MRS University Chapters. This Committee hosts the Graduate Student Mixer at the MRS Spring and Fall Meetings and also manages the reimbursement of student travel funds (each University Chapter is entitled to $\$ 500$ per calendar year for travel to MRS Spring and Fall Meetings.)

The Committee recently initiated a "Special Projects Program" to give financial support to University Chapters to produce educational materials in a transferable medium (videotape, demonstration kits, etc.). The Alfred University Chapter, the first to receive 1991 funding, is making a videotape on the "Rheology of Mud" to introduce the idea of rheology to high school students and undergraduates. For more information about the Special Projects Program, contact me at the address above or Anne Wagner at MRS headquarters.

The Academic Affairs Committee also coordinates the printing and distribution of the Student University Chapter Newsletter. This newsletter is compiled by the University Chapters and distributed twice each year. Anne Wagner, the AAC liaison at MRS headquarters, manages the printing and mailing of the Committee's newsletter.

The Committee has teamed with the Continuing Education and the Public Relations Committees in starting a dialogue on grassroots materials education at levels $\mathrm{K}$ 12. It is clear that students' first impressions of science and engineering have a large impact on their career choices.

Finally, we are formulating a proposal to introduce a new MRS award to recognize excellence and innovation in teaching materials science. We are working on the requirements and guidelines for this award.

\section{Awards Committee}

Chair, J. Murray Gibson, University of Illinois-Urbana, Department of Physics, Loomis Laboratory of Physics, $1110 \mathrm{~W}$. Green Street, Urbana, IL 61801; phone (217) 333-2997; fax (217) 333-9819.

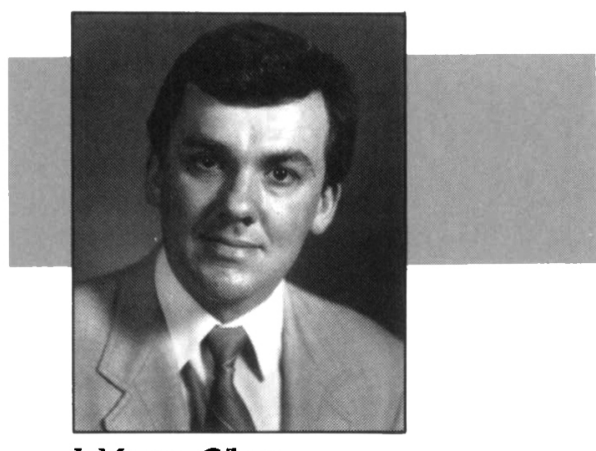

\section{J. Murray Gibson}

The Awards Committee continues a busy schedule for 1991 with the inauguration of another new award, the Outstanding Young Investigator Award. This award recognizes outstanding, interdisciplinary scientific work in materials research by a young scientist or engineer. The awardee must also show exceptional promise as a developing leader in the materials area. The first award will be presented at the 1991 MRS Spring Meeting.

Nominations for this award were due by December 1990, and we received a large number of well-qualified nominations, so the winner is assured to be of very high caliber. The decision-making process is in the hands of a special subcommittee chaired by Wayne Goodman. We will, of course, solicit nominations later this year for the second award, to be presented at the 1992 MRS Spring Meeting.

The MRS Medal program was successfully inaugurated last year with the presentation of the first two awards to Arthur Freeman and Duward Shriver, at the 1990 MRS Fall Meeting. We are now soliciting nominations for this year's awards, and the nomination procedures are published elsewhere in this issue. Nominations from last year remain active for three years. Potential nominators are reminded that the Medal is given for a specific and clear materials innovation, rather than for lifetime achievement. We commend John Baglin for his work in running the Medals Subcommittee.

The Graduate Student Awards have blossomed over the last few years; competition, and thus the stature of the awards, has grown with time. We plan to continue selecting finalists to give oral presentations to judges at the Spring and Fall Meetings, and to choose award winners from among the finalists. We commend Kathy Taylor for her excellent work running the Graduate Awards Program, which she will continue this year.

The Von Hippel Subcommittee, chaired this year by the immediate past president, Russ Chianelli, will have the difficult task of maintaining the extremely high standards of previous Von Hippel awardees. New nominations for this most important award are actively sought.

The Awards Committee is busy adminis- 
tering the growing portfolio of MRS awards. We believe that recognizing signal achievements in materials science is an important job. Beyond giving credit where it is due, these awards also enhance the stature of role models who exemplify the interdisciplinary character of the Materials Research Society. The committee is also considering the need for new awards in teaching and affirmative action. Identifying a source of funding is, of course, always an important part of the consideration.

We are always eager to hear suggestions from members, and also recognize through the last membership survey (see article elsewhere in this issue), that the majority feels that we have enough awards at this time.

\section{Continuing Education Committee}

Chair, Ronald M. Anderson, IBM East Fishkill Facility, B/630 Zip E-70, Hopewell Junction, NY 12533; phone (914) 892-2225; fax (914) 892-2555.

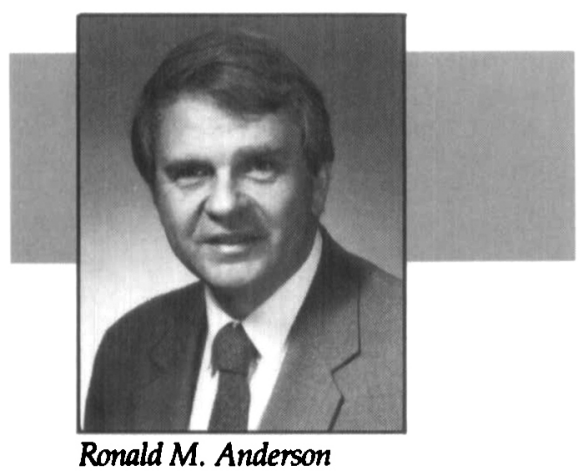

Short Course Manager, Vivienne Harwood Mattox, 440 Live Oak Loop, Albuquerque, NM 87122; telephone (505) 294-9532; fax (505) 298-7942.

The Continuing Education Committee has adopted a long-range mission plan with the following overall focus:

- To be of service to MRS members and the materials science community by providing relevant topical courses that complement the technical program of MRS meetings.

- To develop and evaluate evolving educational forums such as on-site programs, video courses, educational resource materials for universities and the materials science community, and the scientific education of our children.

- To investigate creative avenues to further enhance the Continuing Education Committee Program.

In coordination with the Academic Affairs and Program Committees, we plan a full program of selected short courses at the 1991 MRS Spring and Fall meetings. These short courses are at the forefront of science and technology and complement the Spring and Fall Meeting symposium topics. Specialty, review, and survey courses are designed to meet the needs of professional scientists, engineers, technical staff, and managers who want to know the latest techniques in characterization and fabrication of materials. This Committee is pleased to be able to offer scholarships to students to attend MRS short courses at a substantial discount and to encourage the involvement of students in MRS.

Six new courses are being offered at the 1991 MRS Spring Meeting: Magnetic Thin Films: Physics and Applications; Amorphous Silicon Technology; Characterization of Diamond Films; Characterization of the Electrical Properties of Electronic Materials; Rapid Thermal Processing-III-VMaterials Systems and Processing Technology; and Environmental, Safety, and Health Aspects of Semiconductor Manufacturing.

The Committee develops new courses as soon as the Program Committee for a future meeting decides on the symposia to be offered. The Committee works with members of the Program Committee and utilizes its own resources to identify instructors, define course outlines, and conduct a critical review of potential new courses before they are presented at meetings. Student questionnaires and interviews are conducted to provide feedback on a new course, and to aid the newcourse fine-tuning process.

The On-Site Short Course Program has developed from the successful presentation of courses at MRS meetings. Any one of the more than 70 short courses in our roster of course topics can be presented at any geographical location, subject to instructor availability. Most on-site offerings occur as a result of satisfied MRS meeting course attendees returning to their organizations and suggesting to their management that the course that they attended be brought in-house so that their colleagues can benefit. Industrial organizations and other professional groups can contact the Short Course Manager for details on the full range of available topics.

The Continuing Education Committee has developed policies and procedures so MRS Sections can offer MRS short courses through the Short Course Manager's Office. In 1991, MRS Sections will be able to offer a short course to complement a local meeting and to raise revenue.

The grassroots materials science education effort will continue to engage our attention. During the 1990 Fall MRS
Meeting, we invited Boston-area school teachers and high school students to meet with astronaut Bonnie Dunbar and to attend her plenary presentation. In cooperation with other MRS committees, we also hosted a "Materials Science Networking Session" during the 1990 Fall Meeting to inform MRS members about the status of the grassroots program and to solicit their input and support. These activities will continue in 1991, in cooperation with concerned federal agencies and other technical societies.

We plan to continue to explore other educational avenues for MRS members. We are still interested in preparing videotapes to enhance live course presentations, and we plan to explore satellite transmission of short courses to remote audiences.

\section{External Affairs Committee}

Chair, Kathleen C. Taylor, General Motors Research Laboratories, Physical Chemistry Department, Warren, MI 48090; telephone (313) 986-2010; $\operatorname{fax}(313)$ 986-8697.

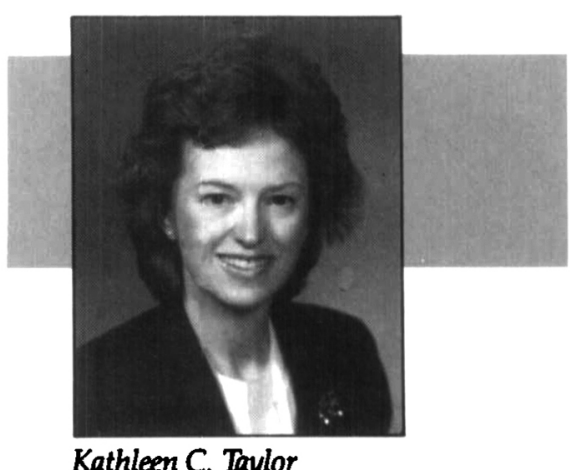

Kathleen C. Taylor

The MRS External Affairs Committee operates through three subcommittees: Domestic Activities, Public Affairs, and International Affairs. The Domestic Activities Subcommittee, chaired by G.E. Pike, Sandia National Laboratories, will continue to implement the MRS Affiliated Organization program. In addition, this Subcommittee will handle correspondence with other U.S.-based technical societies, and prepare and make recommendations on co-sponsorship and endorsement requests.

The Public Affairs Subcommittee, chaired by E.N. Kaufmann, Argonne National Laboratory, will maintain its oversight and implementation of the MRS office in Washington, DC, which pursues activities on behalf of MRS which are related to information flow to and from federal agencies and other sources. This Subcommittee will also continue implementation of the Materials Societies Coordination Panel. 
The International Relations Subcommitee, chaired by C.W. White, Oak Ridge National Laboratory, will foster actions on behalf of MRS with the international materials science community. The 1991 MRS Fall Meeting will continue to provide a venue for meetings of the delegates of the International Union of Materials Research Societies (IUMRS). An MRS representative will attend the International Conference on Advanced Materials in Strasbourg, France, May 27-31, 1991, organized by IUMRS.

In addition to these subcommittee activities, the External Affairs Committee will handle requests from government institutions for information or assistance. As the need arises, the Committee will also sponsor special events at MRS meetings (e.g., panels or discussion groups) that serve the entire materials research community.

\section{Finance Committee}

Chair, J. Francis Young, University of Illinois, Center for Cement Composite Materials, 202A Ceramics Building, $105 \mathrm{~S}$. Goodwin Avenue, Urbana, IL 61801; phone (217) 244-6210; fax (217) 244-6917.

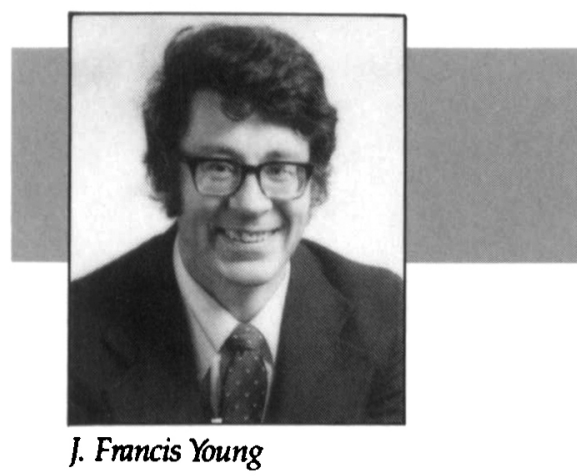

During the past year the Finance Committee completed two important tasks. The first was to review the annual audit report and initiate appropriate follow-up actions. The Committee also recommended to Council a bylaw change to establish a special audit committee of Council for future review. Second, a final version of an official investment policy was approved and sent to the Executive Committee for its review.

The Finance Committee is one of the smaller and least visible of the Society's many committees. Many of the important functions that were originally the responsibility of this Committee (e.g., preparing the annual budget) are now performed by the MRS headquarters staff. The Committee has been recently repositioning itself to serve more as a resource for the Society, to assist in the assessment of the financial im- pact of the longer range plans, and the review of business practices and policies. For example, in the coming year the Committee will review procedures for collecting delinquent accounts, and initiate a review of policies regarding publications inventories. By attention to these relatively mundane matters the Committee hopes to help the MRS work more effectively on behalf of its members.

\section{Long-Range Planning Committee}

Chair, John E.E. Baglin, IBM Almaden Research Center, 650 Harry Road K34/802, San Jose, CA 95120-6099; phone (408) 9272280; fax (408) 927-2100.

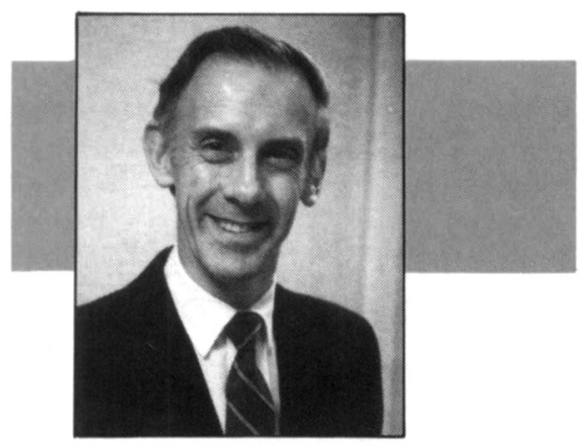

John E.E. Baglin

The Long-Range Planning Committee's primary task for 1991 will be to develop strategic plans for MRS to achieve the impressive set of 10-year goals set for the Society last year. In nearly every aspect of MRS activity (such as meetings, publications, education, etc.), we have before us a challenging wish list. Now it is time to turn it into the reality of practical and reasonable ways to achieve MRS future development and enterprise. In this process, input will be sought broadly from MRS members, staff, and volunteers. We aim to assemble the plan with a "Big Picture" concept of how MRS could look 10 years from now, and to identify actions that we can begin taking to accomplish that vision.

The plan must be a living document, constantly revised and updated to address the 10-year horizon in light of the changes in the world around us. We must adopt new technologies-but choose the right time to do so; we must extend our meeting activities-but not lose the quality of our interactions in the process. And so on. The second task before the Committee, therefore, is to institute a procedure to review and update the Society plan regularly, at the same time monitoring the success and progress of the current plan.

We feel that sound long-term planning is essential for a dynamic Society such as ours-not as a constraint, but as a catalyst to future achievement. Comments and input from all members will be welcomed by the Committee Chair. Members are urgently requested to respond thoughtfully and imaginatively when this Committee solicits their ideas.

\section{Membership Committee}

Chair, Michael J. Kelley, du Pont Experimental Station, Route 141, Building 304, Engineering, P.O. Box 80304, Wilmington, DE 19880-0304; phone (302) 695-3829; fax (302) 695-2504.

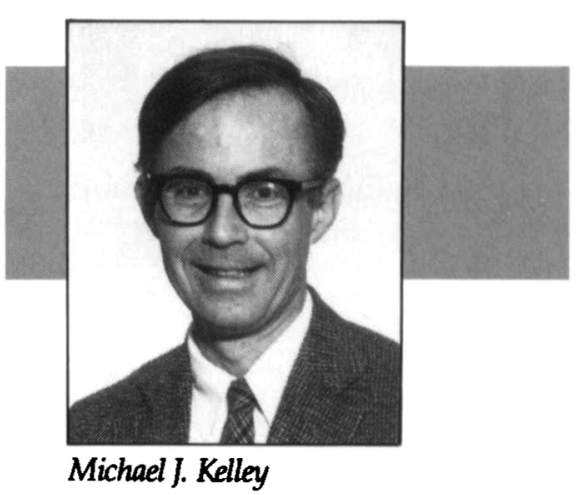

Our major thrust is a program proposed to MRS leadership to begin a vigorous effort to foster MRS local sections throughout the country. This is a change in stance from providing low-level assistance to locally initiated efforts and will bring MRS in line with the major professional societies, if accepted.

We are continuously expanding our endeavors to invite and retain in MRS membership all those who can benefit from it, an ever-widening circle as our vision of MRS grows. We plan to achieve electronic mail connection to MRS headquarters in the next year or so. Finally, we are working with headquarters staff to make the Membership Directory financially self-sustaining. Continually increasing postal rates are a problem, however, as they are for the journals and all other member communications.

\section{Nominating Committee}

Chair, Russell R. Chianelli, Exxon Research and Engineering, Room LB-250, Clinton Township, Route 22 East, Annandale, NJ 08801; phone (201) 730-2563; fax (201) 730-3279.

The Nominating Committee is responsible for constructing a well-balanced slate of candidates for the positions of officer or councillor of MRS, a slate which Council must endorse before the annual election is held during the summer. It is always this 


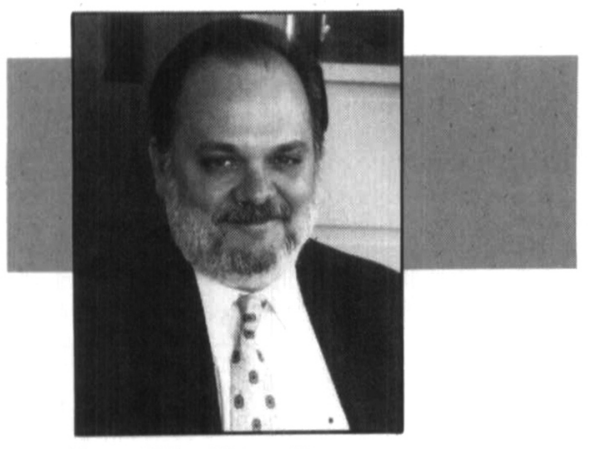

Russell R. Chianelli

Committee's goal to seek excellent, enthusiastic and capable people, and also to maintain within the Council and Executive Committee a healthy representation of the disciplines of our members and to maintain sound representation from academia, industries, and government laboratories.

\section{Program Committee}

Chair, Paul S. Peercy, Sandia National Laboratories, Department 1140, P.O. Box 5800, Albuquerque, NM 87185; phone (505) 844 4309; fax (505) 846-2009.

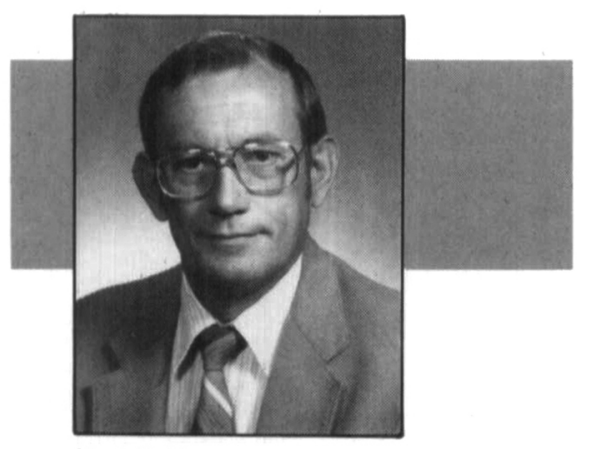

Paul S. Peercy

The MRS Program Committee provides guidance and coordination for technical programming. In a broader sense it is the Program Committee's responsibility to ensure that the "MRS Spirit"-the exciting atmosphere and interdisciplinary environment of technical meetings-is preserved and enhanced. Clearly the quality of our technical meetings must remain the Society's highest priority. Only by maintaining exceptional quality can we enlist the involvement of the most outstanding people; ultimately it is the people who make the difference.

The Program Committee is composed of appointed members, the first vice president, and the Spring and Fall Meeting chairs for the current and immediate past two years. The Committee has previously focused on reviewing the technical sympo- sia proposed by the meeting chairs. The Committee also serves as a focal point for the input of new ideas for symposia and for concerns about program coverage. The innovation for the meetings over the years has really come from the meeting chairs with input from the membership. It is essential that the meeting chairs continue to provide the technical vitality for the MRS meetings and that the Program Committee do everything it can to nourish that process.

The input of many people is required in establishing the final program for our Spring and Fall Meetings, and the Program Committee is at the heart of the process. In onder to provide more effective and timely feedback to meeting chairs, a Program Development Subcommittee was established. It is currently chaired by Julia Phillips, AT\&T Bell Laboratories. This Subcommittee reviews the proposed program with meeting chairs about 14 months in advance of the meeting, with special consideration to program balance, coverage of major constituencies, and potential problems or conflicts. This review allows making program adjustments at an early stage so that MRS can have a balanced technical program in place 12 months in advance of the meeting. In addition, symposia covering exciting new developments can be incorporated as needed. This strong but flexible programming is something few other societies achieve.

At present, the Program Committee is actively working to develop high quality, coordinated programs for the 1992 Spring and Fall Meetings. We are also continuing to look for better ways to ensure that we meet the programmatic needs of our constituencies. For example, we develop topical and regional conferences in addition to the Spring and Fall Meetings. This year we introduced a new meeting, the Washington Materials Forum, held February 28March 1, 1991, in conjunction with the Solid State Sciences Forum on February 27. The Washington Materials Forum was cosponsored by seven major technical societies. It contained a plenary session on "Industrial Competitiveness and Consortia" as well as symposia on "Superconducting Thin Films for Electronic Applications" and "The Science Behind Semiconductor Processing: Advances in Plasma and CVD Research." This meeting was designed not only to provide participants with a technical forum but also to give them access to the Washington community. Finally, in another new programming activity for MRS, an international workshop on "Science and Technology of Thin Films for the 21st Century" is being organized for the summer of 1991. (See
Calendar listing under July 29-August 2 in this issue.)

\section{Public Relations and Publicity Committee}

Chair, June D. Passaretti, Pfizer Minerals Research Center, MPM Division, 9 Highland Avenue, Bethlehem, PA 18017; phone (215) 861-3431; fax (215) 861-3412.

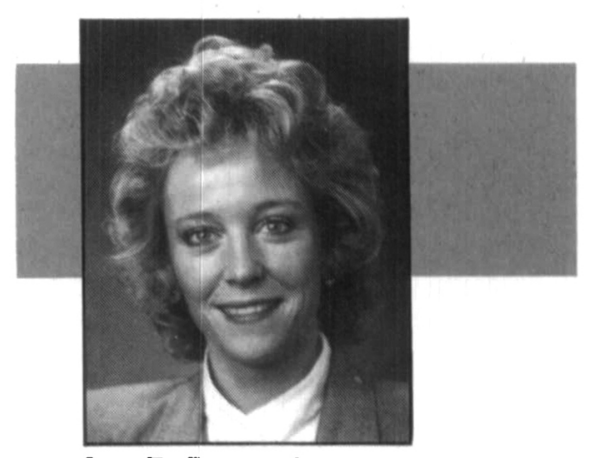

June D. Passaretti

The Public Relations and Publicity Committee was established in 1984 to publicize the MRS activities to members through the MRS Bulletin, and to nonmembers through articles and calendar entries in appropriate journals. Although the Committee still performs these functions, its role has grown in response to the increased membership and recognition of the Society as a major forum for materials research.

Over the next year, the PR\&P Committee will focus on obtaining public recognition as an organization that is the vital link between fundamental research and the technological advances that benefit humanity. Publicity about MRS activities may help inform the general public about materials research and the importance of science education so that when the government makes funding or policy decisions that affect the above, the decisions are made in the environment of a knowledgeable public. The Committee works with MRS members and the media to accomplish these tasks.

For example, for each Spring and Fail Meeting, the symposium organizers nominate a select number of speakers to write lay language abstracts of their presentations for inclusion in the press kits. In addition, some abstracts are rewritten (with the authors' permission) as press releases for distribution before and during the meeting. The press and media specialists are well represented at each meeting and many of the abstracts and releases become feature articles in consumer and technical journals, science sections of major newspapers, and occasionally appear on television news. 
The current Committee, comprised of member volunteers who serve for a threeyear period, represent the East and West Coast and Europe. Since 1990, the Committee has also had staff support at MRS headquarters to act as liaison between members, the PR\&P Committee, and the press, to coordinate publicity efforts for the meetings, ensure continuity of long-range contacts with the press and the technical community, and enable MRS to reply to the increasing number of press inquiries that occur year round.

The future of both science and technology in the United States and the policies affecting both are enhanced by the resources of the Materials Research Society. The Public Relations and Publicity Committee will continue to pursue all possible opportunities to advance this position of MRS and its members.

\section{Publications Committee}

Chair, Peter P. Pronko, Universal Energy Systems, Materials Research Division, 4401 Dayton-Xenia Road, Dayton, $\mathrm{OH}$
45432; phone (513) 426-6900; fax (513) 4265718.

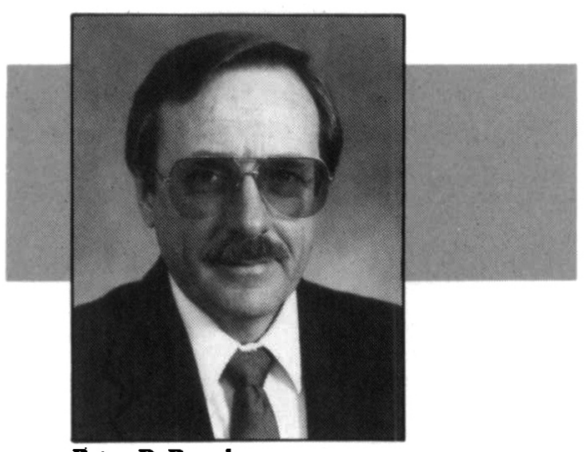

Peter P. Pronko

The Publications Committee is responsible for overseeing the quality of MRS books, Joumal of Materials Research, and the MRS Bulletin to ensure that they are timely, relevant, and broadly available to the scientific community.

Our book program, which currently consists of over 250 titles, will continue to be reviewed to ensure rapid publication and distribution worldwide. Syd Wilson (Mo- torola), chairman of the Book Subcommittee, oversees this activity.

Joumal of Materials Research, now in its sixth year of publication, has been extremely successful in attracting highquality research papers and reaching materials scientists through libraries and MRS members. The Committee will work this year to develop and implement a plan for the next five years so that JMR's form and format, contents and distribution system are the most effective possible. Paul Peercy (Sandia National Laboratories), chairman of the Journal Subcommittee, will work with Editor-in-Chief Walter Brown (AT\&T Bell Laboratories) and the Committee on this project.

The MRS Bulletin, which recently acquired the services of Elizabeth L. Fleischer as technical editor on a full-time basis, will expand its coverage of international events and even broader topical focus issues. The Committee will be working with Elton $N$. Kaufmann (Argonne National Laboratory), chairman of the Bulletin Editorial Boards, to foster the continued editorial growth of the Bulletin.

MIR

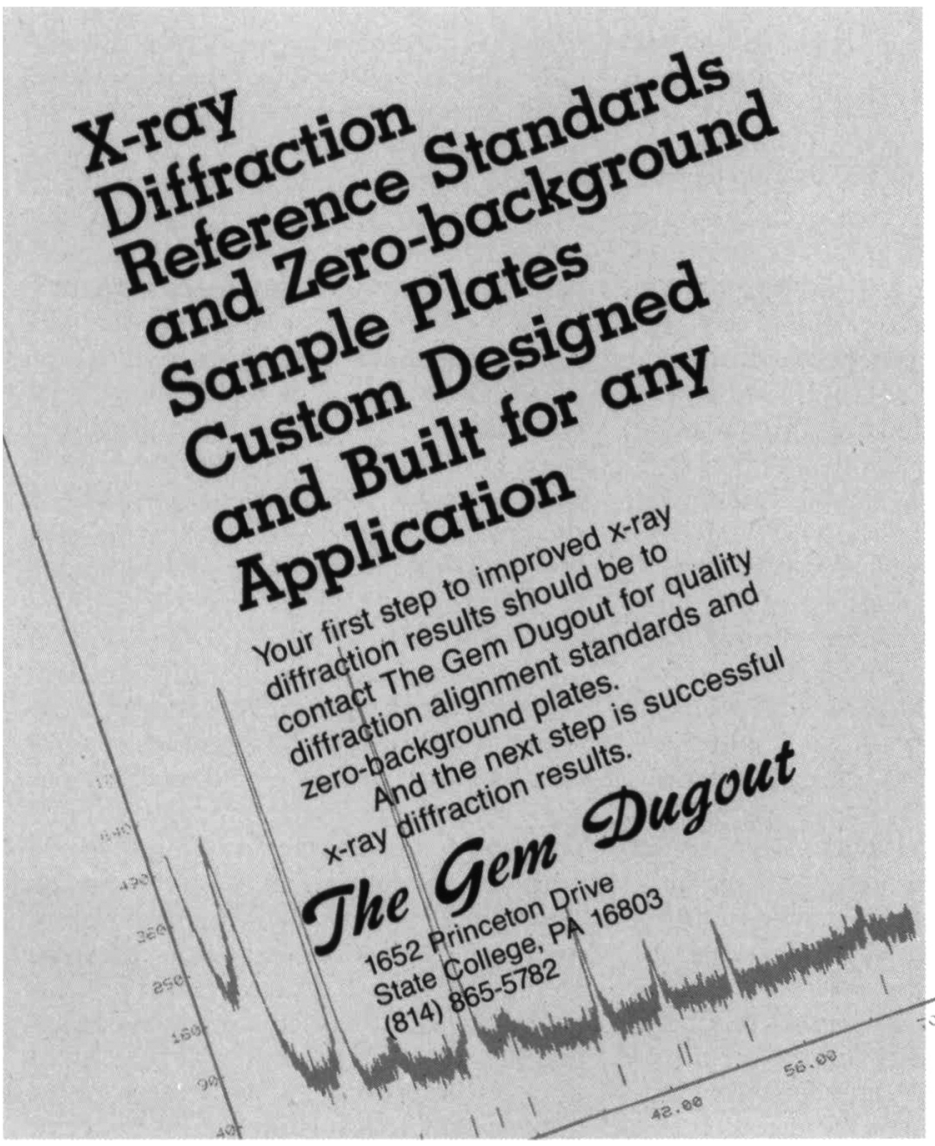

Circle No. 23 on Reader Service Card.

\section{IMAGE ANGSTROMS TO MICRONS Laboratory Service Provided}

ATOMIC FORCE MICROSCOPY

SCANNING TUNNELING MICROSCOPY SCANNING TUNNELING SPECTROSCOPY

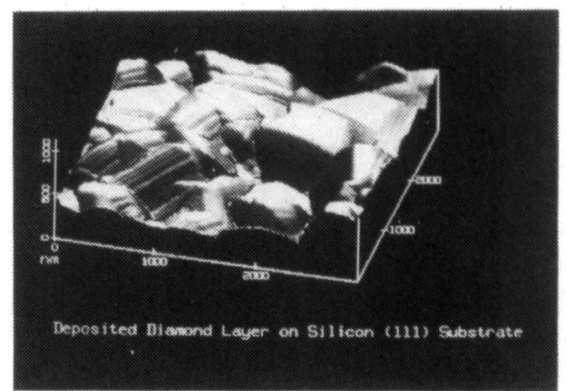

DIAMOND: Deposited by Prof. John Angus, Case WR Univ.

Surface analysis and roughness done on ceramics, metals, polymers, semiconductors. Typicol applications:

$\begin{array}{ll}\text { Sputtered and plated surfaces } & \text { Polished surfaces } \\ \text { CVD and ion implantation } & \text { Integrated circuits } \\ \text { Computer disks and tapes } & \text { Corrosion \& wear }\end{array}$

Contact: Dr. Thomas L. Altshuler (508) 369-9033

Advanced Materials Laboratory, Inc.

242 Baker Avenue, Concord, MA 01742

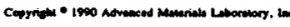

Circle No. 24 on Reader Service Card. 
(As of February, 1991)

Advanced Control Systems Corporation

Advanced Energy Industries, Inc.

Advanced Materials Laboratory, Inc.

Advanced Micro Devices, Inc.

Aerospace Corporation

AET addax, Inc.

AG Associates

Air Products and Chemicals, Inc.

Aixtron $\mathrm{GmbH}$

Akzo America Inc.

Alcan International Limited

Alcatel NV

Alcoa

Alliance Analytical

Allied-Signal inc.

American Cyanamid Company

Amoco Corporation

Amoco Chemical Corporation

Amoco Oil Co.

Amoco Technology Company

Anatech Ltd.

Angstrom Sciences

APD Cryogenics Inc.

APL Engineered Materials, Inc.

Applied Materials, Inc.

Applied Science and Technology, Inc. (ASTeX)

Argonne National Laboratory/IPNS

Asahi Glass Company, Ltd.

Atomic Energy of Canada Limited

AT\&T Bell Laboratories

Bandgap Technology Corporation

Barbeau-Hutchings Advertising, Inc.

Bell Communications Research, Inc.

Billiton Precursors B.V.

Bio-Rad Laboratories

Blake Industries, Inc.

Bomem Inc.

BP America Research \& Development

British Telecom Research Labs

Brookhaven National Laboratory

Bruker Instruments Inc.

Butterworths Scientific Ltd.

California Institute of Technology

Cameca Instruments, Inc.

Center for Materials Fabrication

Centorr Furnaces/Vacuum Industries

Chronar Corporation

Cober Electronic, Inc.

Coherent Laser Group

Commonwealth Scientific

Corporation

Computer Graphic Service (CGS)

Conversion Technology Corporation

Corning Inc.

CrystaComm, Inc.

Crystallume

CVC Products, Inc

David Sarnolf Research Center

Denton Vacuum Inc.

Diamond Materials, Inc.

Digital Instruments, Inc.

Doty Scientific, inc.

The Dow Chemical Company

Dow Corning Corporation

Eastman Kodak Company

Eaton Corporation

EG\&G Idaho, Inc.

EG\&G Princeton Applied Research

E.I. duPont de Nemours \& Company
Electric Power Research Institute (EPRI)

ElectroScan Corporation

Elettrorava S.p.A

Elsevier Science Publishers B.V.

Emcore Corporation

Energy and Environmental Research Center (EERC)

Engelhard Corporation

EPI Division Chorus Corporation

Epitaxial Products International, Ltd.

Epitronics Corporation

Charles Evans \& Associates

Evans East, Inc.

Exxon Basic Chemicals Technology

Exxon Research \& Engineering Co.

FEI Company

E.A. Fischone Instruments Manufacturing

FleXus Incorporated

Ford Motor Company

Forest Products Laboratory

Friendship United Corporation

Fuji Electric Co., Itd.

Fuji Xerox Co., Ltd.

Fujitsu Lid.

Galileo Vacuum Systems

Gatan, Inc.

Gelest Inc.

General Electric Corporation

General Electric Corp./Advanced Inorganic Materials Lab.

General Electric Corp./Aircraft Engines Division

General Electric NMR Instruments

General Motors Research Laboratories

Gerling Laboratories

Getty Conservation Institute

Glasstech Solar, Inc. (GSI)

Goodfellow Corporation

Granville-Phillips Company

GTE Laboratories Inc.

Hewlett-Packard, NMD

High Voltage Engineering Europa

B.V.

Hitachi Ltd.

Hitachi Scientific Instruments

Hoechst Celanese Research Division

Hoya Optics, Inc.

HTR Sciences

Hughes Research Laboratories

Huntington Laboratories

IBM Corporation

IBM Japan, Ltd.

$\mathrm{ICl}$ Polyurethanes

Imperial Chemical Industries

Innovative Technology, Inc.

INSPEC/IEE

Instron Corporation

Instruments S.A., Inc./Riber Division

Intel Corporation

International Scientific Instruments, Inc.

Ion Tech, Inc.

Ionic Atlanta

lowa Fly Ash

Janis Research Company, Inc

JCPDS - International Centre for

Diffraction Data

JEOL U.S.A., Inc.
Johnson \& Johnson Orthopaedics, Inc.

Kennametal, Inc.

Kluwer Academic Publishers

Kobe Development Corporation

Kopin Corporation

Kratos Analytical, Inc

Kyocera Corporation

Lake Shore Cryotronics, Inc.

Lam Research Corporation

Lambda Physik, Inc.

Lawrence Livermore National Laboratory

Lehighton Electronics, Inc

Kurt J. Lesker Company

Leybold Vacuum Products, Inc.

Los Alamos National Laboratory

Manics

Martin Marietta Energy Systems, Inc.

Martin Marietta Laboratories

Matec Instruments, Inc

Materials Research Corporation

Matheson Gas Products

Matsushita Electrical Industrial Co.

MCC (Microelectronics \& Computer Technology Corporation)

MDC Vacuum Products Corporation

MEMC Electronic Materials Inc.

Micromap Corp.

Microscience, Inc.

MKS Instruments, Inc.

Mobay Corporation

Mobil Research \& Development Corporation

Molycorp, Inc. (a Unocal Company)

Monsanto Company

MR Semicon, Inc.

Nano Instruments, Inc.

NASA Lewis Research Center

National Electrostatics Corporation

National Semiconductor

NEC Research Institute Inc.

New York State College/Ceramics

Nippon Mining Company, Ltd.

Nippon Telegraph \& Telephone Corporation

Nissei Sangyo America, Ltd.

Noran Instruments, Inc.

North Eastern Analytical Corporation

Northern Telecom Electronics Ltd

Norton Company

Oak Ridge National Laboratory

OIS, Inc. (Optical Imaging Systems, Inc.)

Ortech International

Oxford Instruments North America inc.

Pacific Northwest Laboratory

Peak Systems, Inc.

Pechiney Corporation

Pergamon Press, Inc

Perkin-Elmer Corp.

Pfizer Inc.

Philips Electronic Instruments Co.

Plasma Sciences, Inc.

PPG Industries Glass R\&D Center $P Q$ Corporation

The Proctor \& Gamble Company

Prometrix Corporation

Quantum Design, Inc.

Rapro Technology Inc.

Raytheon Company
Rhone-Poulenc Inc.

Rigaku USA Inc.

Riken Corporation

Rockwell International Science Center

Sandia National Laboratories

Sanyo Electric Co., Ltd.

Schlumberger-Doll Research

Scienta Instruments AB

Scintag, Inc.

Sharp Corporation

Shell Oil Company

Shoei Gloss Company, Ltd.

Siemens Analytical X-Ray Instruments, Inc.

Siemens Solar Industries

Solar Energy Research Institute (SERI)

Solarex Corporation

Solid State Measurements, Inc.

South Bay Technology, Inc.

Spex Industries, Inc.

Spire Corporation

Springer-Verlag New York, Inc

SSC, Inc.

Staib Instrumente $\mathrm{GmbH}$

Strem Chemicals, Inc.

Sumitomo Electric USA, Inc.

Sumitomo Electric Industries, Lid.

Sumitomo Metal Mining Co., Ltd.

Superconductive Components, Inc.

Superconductivity Publications, Inc.

Surface Science Laboratories, Inc.

Tamarack Scientific Co., Inc.

TDK Corporation

Technics, Inc.

Texas Instruments, Inc.

3M Company

Toei Industry Co., Ltd.

Toyobo Co., Ltd.

Ultra High Vacuum Instruments Inc.

Ultratherm Inc.

ULVAC Japan, Ltd.

United Technologies Research Center

Universal Energy Systems, Inc. (UES)

UOP

USG Research Center

Vacuum/Atmospheres Company

Vacuum Barrier Corporation

Varian Assocs., Inc./Continental Electronic Div.

Varian Assocs., Inc./Ion Implant Systems

Varian Assocs., Inc. /Thin Film

Technology Div.

VCH Publishers, Inc

VG Instruments, Inc.

VG Microscopes Ltd.

Virginia Semiconductors, Inc.

Voltaix, Inc.

Wacker Siltronic Corporation

Wavemat Inc.

Westinghouse Science \&

Technology Center

W.R. Grace \& Company

W.R. Grace \& Co./Research and

Davison Chemical Div.

Xerox Corporation

XMR Incorporated

Carl Zeiss, Inc. 